\title{
Weed Interference in the sugarcane (Saccharum officinarum L.) plantations of Ethiopia
}

\author{
Firehun Yirefu $^{1}$, Tamado Tana ${ }^{2,}$, , Abera Tafesse ${ }^{1}$, Yohannes Zekarias ${ }^{1}$ \\ ${ }^{1}$ Ethiopian Sugar Corporation Research and Training, P.O. Box 15, Wonji, Ethiopia \\ ${ }^{2}$ Haramaya University, P.O.Box, 138, Dire Dawa, Ethiopia
}

\section{Email address:}

firehunyirefu@yahoo.com (F. Yirefu), tamado63@yahoo.com (T. Tana), aberatafesse@yahoo.com (A. Tafesse), johnatamas@yahoo.com (Y. Zekarias)

\section{To cite this article:}

Firehun Yirefu, Tamado Tana, Abera Tafesse, Yohannes Zekarias. Weed Interference in the Sugarcane (Saccharum officinarum L.) Plantations of Ethiopia. Agriculture, Forestry and Fisheries. Vol. 2, No. 6, 2013, pp. 239-247. doi: 10.11648/j.aff.20130206.17

\begin{abstract}
Field experiments involving sprawling and erect cultivars of sugarcane and 12 weed competition periods were conducted in randomized complete block design in four replications for two cropping seasons at three sugarcane plantations of Ethiopia. Sugarcane was either kept free of weeds or weeds were allowed to grow for 0, 3, 6, 9, 12 and 15 weeks after planting (WAP). The sprawling sugarcane cultivars ('B41227' and 'N14') suppressed weed growth more and gave higher cane yield than the erect cultivar 'NCo334'. The cane yield loss in unweeded plots compared to weed free plots ranged from $69.7 \%$ for sprawling cultivar 'B41227' at Methara to $83.5 \%$ at Wonji-Shoa for the erect cultivar 'NCo334'. The beginning and end of critical periods of weed interference on $5 \%$ acceptable cane yield loss levels ranged from about 2.5 to 14 WAP for the erect cultivar and from 3 to 13.5 WAP for the sprawling cultivars implying the need to use herbicides or other weed control methods in sugarcane plantations of Ethiopia during these periods to keep cane yield loss levels below 5\%.
\end{abstract}

Keywords: Cane Yield, Critical Period of Weed Competition, Gompertz Equation, Logistic Equation, Weeks After Planting

\section{Introduction}

The sugar industry plays a significant role in Ethiopian economy. Sugarcane is cultivated on about 37,000 ha and the four sugar factories produce about 300,000 tons of sugar per year [1]. However, the current sugar production provides only $60 \%$ of the annual demand for domestic consumption and the annual per capita consumption of sugar in Ethiopia was about $5.1 \mathrm{~kg}$ which is considered to be low even by African standards (16.3 kg) [2]. Thus, there is a high need to increase the production and productivity of sugarcane in order to have a reliable supply of sugar in the country.

However, the yield of sugarcane is limited by many factors among which weeds are the major constraints of sugarcane production. Sugarcane being a long duration and widely spaced crop, it provides an ample opportunity for several weeds to grow in vacant space, right from planting to harvesting. In sugarcane production, cane yield losses ranging from $20-90 \%$ were reported due to weeds in different countries of the World [3]. In Ethiopia, weeds caused cane yield loss that ranged from $64-80 \%$ in the sugarcane plantations if not controlled [4]. Moreover, financial records of sugarcane plantations of Ethiopia indicate that weed control costs of about 2.5 million Ethiopian Birr (1 USD = 19.3546 ETB on 29/11/2013) per year [5].

To reduce the amount of herbicides used for weed control in sugarcane, both for economical and environmental reasons, an Integrated Weed Management (IWM) involving a combination of cultural, mechanical, biological, genetic, and chemical methods has become a priority [6]. To achieve this, there is a need for better understanding of sugarcane-weed interactions and identification of critical periods of weed competition with respect to crop growth.

The critical period of weed control (CPWC) is the time period in the crop growth cycle during which weeds must be controlled to prevent unacceptable yield loss [7]. The CPWC represents the time interval between two separately measured components: the maximum weed-infested period and the minimum weed-free period.

Information on the CPWC in sugarcane could help improve timing of post-emergence herbicide applications and also to improve the efficiency of weed management through cultivation. Reducing the number of herbicide treatments as a result of better timing and efficiency can reduce environmental 
contamination and cost of production [8].

Thus, the present study was undertaken to assess the effect of durations of weed interference on weed dry weight and millable cane yield; and to determine the critical period of weed control for sprawling and erect cultivars of sugarcane at the three sugarcane plantations of Ethiopia.

\section{Materials and Methods}

\subsection{Description of the Experimental Sites}

Field experiments were conducted at three sugarcane plantations of Ethiopia; Wonji-Shoa $\left(8^{\circ} 30^{\prime} \mathrm{N}, 39^{\circ} 20^{\prime} \mathrm{E}\right.$, altitude of $1540 \mathrm{~m}$ a.s.1.); Methara $\left(8^{\circ} 00^{\prime} \mathrm{N}, 39^{\circ} 52^{\prime} \mathrm{E}\right.$, altitude of $950 \mathrm{~m}$ a.s.1.) and Finchaa $\left(10^{\circ} 00^{\prime} \mathrm{N}, 37^{\circ} 30^{\prime} \mathrm{E}\right.$, altitude of $1650 \mathrm{~m}$ a.s.1.). The soil types of the experimental sites are: light clay at Wonji-Shoa with a $\mathrm{pH}$ of 7.5 , organic matter of $2.2 \%$, total nitrogen of $0.10 \%$ and available phosphorus of $7.4 \mathrm{ppm}$; clay loam at Methara with a $\mathrm{pH}$ of 8.7 , organic matter of $1.0 \%$, total nitrogen of $0.10 \%$ and available phosphorus of $2.5 \mathrm{ppm}$; and light clay at Finchaa with a $\mathrm{pH}$ of 5.8 , organic matter of $3.3 \%$, total nitrogen of $0.13 \%$, and available phosphorus of $5.5 \mathrm{ppm}$. Wonji-Shoa receives an average annual rainfall of $831 \mathrm{~mm}$, with mean annual maximum and minimum temperatures of $27^{\circ} \mathrm{C}$ and $15^{\circ} \mathrm{C}$, respectively; Methara receives an average of $554 \mathrm{~mm}$ annual rainfall, with mean annual maximum and minimum temperatures of $32.6^{\circ} \mathrm{C}$ and $17.4^{\circ} \mathrm{C}$, respectively; and Finchaa receives an average of $1250 \mathrm{~mm}$ annual rainfall, with mean annual maximum and minimum temperatures of $31.0^{\circ} \mathrm{C}$ and $15.0^{\circ} \mathrm{C}$, respectively.

\subsection{Treatments, Experimental Design and Crop Management}

Factorial experiments involving sprawling and erect cultivars of sugarcane and 12 weed competition treatments were conducted in randomized complete block design in four replications for two cropping seasons (2004-2006 and 20072008). The sprawling sugarcane cultivars $\left(30-50^{\circ}\right.$ leaf angle) used for the study were 'N14' at Wonji-Shoa and Finchaa and 'B41227' at Methara and 'NCo334' having erect growth habit $\left(70-90^{\circ}\right.$ leaf angle) was used at all the three plantations. The weed competition treatments consisted of six initial weed-free periods in which plots were kept free of weeds for $0,3,6,9,12$ and 15 weeks after planting (WAP) of sugarcane and then weeds were allowed to grow until harvest and six initial weed-infested periods in which, weeds were allowed to grow for $0,3,6,9,12$ and 15 weeks after planting (WAP), after which the plots were kept free of weeds until harvest by periodic hand hoeing. Naturally occurring weed populations were used in all the trials.

Plot size was six furrows of five meter length $\left(43.5 \mathrm{~m}^{2}\right)$ where 35 two budded setts were planted in each furrow overlapping by five centimeters. The methods of irrigation used were blocked end furrow at Wonji-Shoa; furrow irrigation using siphon tubes at Methara and dragline sprinkler at Finchaa. Fertilizer sources and rates used were
Urea $(46 \% \mathrm{~N})$ at rate of $200 \mathrm{~kg} \mathrm{ha}^{-1}$ at Wonji-Shoa; Ammonium Sulphate Nitrate $(26 \% \mathrm{~N})$ at rate of $400 \mathrm{~kg} \mathrm{ha}^{-1}$ at Methara and Diammonium Phosphate $\left(18 \% \mathrm{~N}, 46 \% \mathrm{P}_{2} \mathrm{O}_{5}\right)$ at the rate of $250 \mathrm{~kg} \mathrm{ha}^{-1}$ and Urea $(46 \% \mathrm{~N})$ at the rate of 150 $\mathrm{kg} \mathrm{ha}^{-1}$ at Finchaa.

\subsection{Data Collection and Statistical Analysis}

Data were collected from the central four furrows. Before harvesting of the canes, a $0.5 \mathrm{~m} \times 0.5 \mathrm{~m}$ quadrat was placed randomly at three places in the central four furrows of each plot to collect the weeds, which were then oven-dried and weighed. Total weed dry weight for each plot was computed on per $\mathrm{m}^{2}$ basis. Millable cane weight was determined at harvest from the central four rows and the yield was converted to tons $\mathrm{ha}^{-1}$.

The effect of treatments on weed dry weight and millable cane yield were subjected to analysis of variance (ANOVA) and means were compared with the Least Significant Difference (LSD) test at 5\% level of significance using STATISTICA software [9]. Data for each site and season were analyzed separately because of differences in sugarcane varieties, weed composition, agro-climate, soil and agronomic practices used.

The relative cane yield of each treatment was calculated as a percentage of the corresponding weed-free cane yield and non-linear regression equations were used to fit the data using STATISTICA software [9]. The Gompertz equation described by [10] was used to predict the relationship between relative cane yields as influenced by the increasing duration of the weed-free period as:

$$
\mathrm{RY}=\mathrm{A} \times \exp [-\mathrm{B} \times \exp (-\mathrm{K} \times \mathrm{T})]
$$

where RY is relative cane yield (\% of season-long weed-free yield), $\mathrm{A}$ is the yield asymptote, and $\mathrm{B}$ and $\mathrm{K}$ are constants and $\mathrm{T}$ is the length of the weed-free period after planting of sugarcane in weeks. Similarly, a three-parameter logistic equation described by [10] was used to predict the effect of increasing duration of weed interference on relative cane yield as:

$$
\mathrm{RY}=\left(\frac{1}{\exp [C \times(T-D)]+F}\right)+\left(\frac{F-1}{F}\right) \times 100
$$

where RY is the relative cane yield (\% of season-long weedfree yield), $\mathrm{T}$ is the duration of weed interference measured in weeks after planting of sugarcane; C, D and F are constants derived by fitting the logistic regression equation.

Using the derived Gompertz equations, the critical duration of the weed-free period for sugarcane in WAP was calculated for acceptable cane yield loss level of $5 \%$. Similarly, using the derived logistic equations, the critical length of weed-infested period was calculated for acceptable cane yield loss level of 5\%. The 5\% cane yield loss level was taken to be acceptable, considering the present cost of weed control in sugarcane plantations in Ethiopia. 


\section{Results and Discussion}

\subsection{Weed Dry Biomass}

Significant differences were observed between the seasons, the cultivars and durations of weed competition in weed dry biomass. Higher total weed dry biomass was observed in the first season (2005-2006) than in the second season (20072008) (Table 1 and 2). Differences between seasons in weed composition and abundance can be attributed to differences in weather, soil and previous management practices used as these factors were reported to influence weed distribution, composition and densities [11, 12]. In general, weed dry biomass decreased with increasing durations of weed free periods (Table 1) and with decreasing durations of weedy periods (Table 2) possibly due to less time for weed seeds to germinate and utilize the environmental resources for a longer period of time. However, the rate of reduction was more remarkable beyond weed free period of 3 WAP (Table 1) and weedy period of 12 WAP (Table 2).

Table 1. Effects of cultivars of sugarcane and increasing duration of weed free periods on weed dry weight $\left(\mathrm{g} \mathrm{m}^{-2}\right)$ at Wonji-Shoa, Methara and Finchaa

\begin{tabular}{|c|c|c|c|c|c|c|c|}
\hline \multirow[b]{2}{*}{$\begin{array}{l}\text { Weed free } \\
\text { Cultvar }^{1} \text { weeks (WAP) }{ }^{2}\end{array}$} & & \multicolumn{3}{|l|}{ 2005-2006 } & \multicolumn{3}{|l|}{$2007-2008$} \\
\hline & & Wonji-Shoa & Methara & Finchaa & Wonji-Shoa & Methara & Finchaa \\
\hline \multirow[t]{6}{*}{ Sprawling } & 0 & 187.09 & 179.68 & 193.74 & 173.99 & 167.10 & 180.18 \\
\hline & 3 & 179.11 & 172.36 & 186.33 & 166.57 & 160.29 & 173.29 \\
\hline & 6 & 97.21 & 90.34 & 109.46 & 90.40 & 84.02 & 101.80 \\
\hline & 9 & 57.88 & 50.36 & 68.46 & 53.83 & 46.83 & 63.67 \\
\hline & 12 & 26.78 & 20.34 & 33.52 & 24.90 & 18.92 & 31.17 \\
\hline & 15 & 8.86 & 5.63 & 12.47 & 8.24 & 5.24 & 11.60 \\
\hline \multirow[t]{6}{*}{ Erect } & 0 & 257.00 & 239.26 & 272.22 & 239.01 & 222.51 & 253.16 \\
\hline & 3 & 208.68 & 196.56 & 226.35 & 194.07 & 182.80 & 210.50 \\
\hline & 6 & 110.55 & 97.62 & 119.59 & 102.81 & 90.79 & 111.22 \\
\hline & 9 & 69.17 & 58.48 & 79.64 & 64.33 & 54.39 & 74.06 \\
\hline & 12 & 33.28 & 27.37 & 41.26 & 30.95 & 25.45 & 38.37 \\
\hline & 15 & 11.87 & 8.18 & 14.26 & 11.04 & 7.61 & 13.26 \\
\hline LSD $(0.05)$ cultivar $\times$ duration & & 10.25 & 10.25 & 10.25 & 10.05 & 10.15 & 9.73 \\
\hline \multicolumn{8}{|l|}{ Significance $^{2}$} \\
\hline & Wonji-Shoa & Methara & Finchaa & & & & \\
\hline Season (S) & $* *$ & $* *$ & $* *$ & & & & \\
\hline Cultivar (C) & $* *$ & $* *$ & $* *$ & & & & \\
\hline Duration (D) & $* *$ & $* *$ & $* *$ & & & & \\
\hline Cultivar $\times$ Duration & $* *$ & $* *$ & $* *$ & & & & \\
\hline
\end{tabular}

${ }^{1}$ The sprawling cultivars used were 'B41227' at Methara and 'N14' at Finchaa and Wonji-Shoa; and the erect cultivar 'NCo334' was used at all the plantations; ${ }^{2} \mathrm{WAP}=$ Weeks After Planting of sugarcane

$2 * *$ indicates significance at $\mathrm{P}<0.01$

Table 2. Effects of cultivars of sugarcane and increasing durations of weedy periods on weed dry weight $\left(\mathrm{g} \mathrm{m}^{-2}\right)$ at Wonji-Shoa, Methara and Finchaa

\begin{tabular}{|c|c|c|c|c|c|c|c|}
\hline \multirow[b]{2}{*}{$\begin{array}{l}\text { Weedy } \\
\text { Cultivar }^{1} \text { weeks (WAP) }{ }^{2}\end{array}$} & & \multicolumn{3}{|l|}{$2005-2006$} & \multicolumn{3}{|l|}{$2007-2008$} \\
\hline & & Wonji-Shoa & Methara & Finchaa & Wonji-Shoa & Methara & Finchaa \\
\hline \multirow[t]{6}{*}{ Sprawling } & 0 & 0 & 0 & 0 & 0 & 0 & 0 \\
\hline & 3 & 9.88 & 5.33 & 12.42 & 9.19 & 4.96 & 11.55 \\
\hline & 6 & 32.95 & 24.36 & 48.68 & 30.64 & 22.65 & 45.27 \\
\hline & 9 & 71.23 & 63.43 & 79.89 & 66.24 & 58.99 & 74.30 \\
\hline & 12 & 181.43 & 174.46 & 189.48 & 168.73 & 162.25 & 176.22 \\
\hline & 15 & 185.94 & 176.16 & 191.21 & 172.92 & 163.83 & 177.82 \\
\hline \multirow[t]{2}{*}{ Erect } & 0 & 0 & 0 & 0 & 0 & 0 & 0 \\
\hline & 3 & 12.06 & 8.1 & 15.35 & 11.22 & 7.53 & 14.27 \\
\hline
\end{tabular}




\begin{tabular}{|c|c|c|c|c|c|c|c|}
\hline \multirow[b]{2}{*}{$\begin{array}{l}\text { Weedy } \\
\text { Cultivar }^{1} \text { weeks (WAP) }{ }^{2}\end{array}$} & & \multicolumn{3}{|l|}{$2005-2006$} & \multicolumn{3}{|l|}{$2007-2008$} \\
\hline & & Wonji-Shoa & Methara & Finchaa & Wonji-Shoa & Methara & Finchaa \\
\hline & 6 & 37.59 & 33.12 & 48.68 & 34.96 & 30.80 & 45.27 \\
\hline & 9 & 79.89 & 71.14 & 85.65 & 74.30 & 66.16 & 79.65 \\
\hline & 12 & 149.19 & 132.62 & 156.32 & 138.75 & 123.34 & 145.38 \\
\hline & 15 & 211.54 & 199.19 & 233.15 & 196.73 & 185.25 & 216.83 \\
\hline \multirow{3}{*}{$\begin{array}{l}\operatorname{LSD}(0.05) \text { cultivar } \times \text { duration } \\
\text { Significance }^{2}\end{array}$} & & 13.08 & 13.69 & 12.92 & 13.15 & 13.77 & 13.00 \\
\hline & & & & & & & \\
\hline & Wonji-Shoa & Methara & Finchaa & & & & \\
\hline Season (S) & $* *$ & $* *$ & $* *$ & & & & \\
\hline Cultivar (C) & ns & ns & $\mathrm{ns}$ & & & & \\
\hline Duration (D) & $* *$ & $* *$ & $* *$ & & & & \\
\hline Cultivar $\times$ Duration & $* *$ & $* *$ & ** & & & & \\
\hline
\end{tabular}

'The sprawling cultivars used were 'B41227' at Methara and 'N14' at Finchaa and Wonji-Shoa; and the erect cultivar 'NCo334' was used at all the plantations; ${ }^{2} \mathrm{WAP}=$ Weeks After Planting of sugarcane

$2 * *$ and ns indicate significance at $\mathrm{P}<0.01$ and non-significanc $(\mathrm{P} \geq 0.05)$, respectively

Table 3. Effects of cultivars of sugarcane and increasing durations of weedy periods on millable cane yield (t ha $\left.{ }^{-1}\right)$ at Wonji-Shoa, Methara and Finchaa

\begin{tabular}{|c|c|c|c|c|c|c|c|}
\hline \multirow[b]{2}{*}{$\begin{array}{l}\text { Weedy } \\
\text { Cultivar }^{1} \text { weeks (WAP) }{ }^{2}\end{array}$} & & \multicolumn{3}{|l|}{$2005-2006$} & \multicolumn{3}{|l|}{$2007-2008$} \\
\hline & & Wonji-Shoa & Methara & Finchaa & Wonji-Shoa & Methara & Finchaa \\
\hline \multirow[t]{6}{*}{ Sprawling } & 0 & 203.23 & 205.15 & 197.94 & 187.35 & 189.12 & 182.48 \\
\hline & 3 & 192.21 & 194.29 & 186.41 & 176.45 & 178.37 & 171.12 \\
\hline & 6 & 158.28 & 161.32 & 150.41 & 145.62 & 148.41 & 138.38 \\
\hline & 9 & 123.19 & 132.46 & 117.27 & 113.33 & 121.86 & 107.89 \\
\hline & 12 & 69.33 & 70.13 & 60.12 & 63.78 & 64.52 & 55.31 \\
\hline & 15 & 62.12 & 71.33 & 59.36 & 57.15 & 65.62 & 54.61 \\
\hline \multirow[t]{6}{*}{ Erect } & 0 & 185.74 & 194.95 & 178.11 & 171.05 & 179.71 & 164.03 \\
\hline & 3 & 179.39 & 186.44 & 173.80 & 164.87 & 171.18 & 159.72 \\
\hline & 6 & 136.46 & 143.52 & 137.47 & 125.54 & 132.04 & 126.47 \\
\hline & 9 & 105.65 & 113.26 & 104.54 & 97.20 & 104.20 & 96.18 \\
\hline & 12 & 78.18 & 84.76 & 76.66 & 71.93 & 77.98 & 70.53 \\
\hline & 15 & 56.17 & 52.12 & 55.27 & 51.68 & 47.95 & 50.85 \\
\hline $\operatorname{LSD}(0.05)$ cultivar $\times$ duration & & 11.57 & 11.93 & 11.40 & 11.41 & 11.94 & 11.44 \\
\hline \multicolumn{8}{|l|}{ Significance $^{2}$} \\
\hline & Wonji-Shoa & Methara & Finchaa & & & & \\
\hline Season (S) & $* *$ & $* *$ & $* *$ & & & & \\
\hline Cultivar (C) & $* *$ & $* *$ & $* *$ & & & & \\
\hline Duration (D) & $* *$ & $* *$ & $* *$ & & & & \\
\hline Cultivar $\times$ Duration & $* *$ & ** & ** & & & & \\
\hline
\end{tabular}

${ }^{1}$ The sprawling cultivars used were 'B41227' at Methara and 'N14' at Finchaa and Wonji-Shoa; and the erect cultivar 'NCo334' was used at all the plantations; ${ }^{2} \mathrm{WAP}=$ Weeks After Planting of sugarcane

$2 * *$ indicates significance at $\mathrm{P}<0.01$ 
Table 4. Effects of cultivars of sugarcane and increasing durations of weed free periods on millable cane yield $\left(t\right.$ ha $\left.{ }^{-1}\right)$ at Wonji-Shoa, Methara and Finchaa

\begin{tabular}{|c|c|c|c|c|c|c|c|}
\hline & & $2005-2006$ & & & $2007-2008$ & & \\
\hline $\begin{array}{l}\text { Weed free } \\
\text { Cultivar }^{1} \text { weeks (WAP) }{ }^{2}\end{array}$ & & Wonji-Shoa & Methara & Finchaa & Wonji-Shoa & Methara & Finchaa \\
\hline \multirow[t]{6}{*}{ Sprawling } & 0 & 57.80 & 62.165 & 55.66 & 52.92 & 56.93 & 50.88 \\
\hline & 3 & 65.57 & 72.905 & 63.85 & 60.58 & 67.33 & 59.07 \\
\hline & 6 & 90.12 & 97.87 & 87.26 & 82.91 & 90.04 & 80.28 \\
\hline & 9 & 127.31 & 136.16 & 122.35 & 117.12 & 125.27 & 112.56 \\
\hline & 12 & 194.63 & 199.26 & 191.23 & 179.06 & 183.32 & 175.93 \\
\hline & 15 & 197.03 & 200.13 & 193.21 & 181.27 & 184.12 & 177.75 \\
\hline \multirow[t]{6}{*}{ Erect } & 0 & 30.68 & 33.16 & 35.85 & 28.23 & 30.51 & 32.75 \\
\hline & 3 & 50.13 & 56.16 & 45.97 & 46.12 & 51.67 & 42.53 \\
\hline & 6 & 80.39 & 87.69 & 74.64 & 73.96 & 80.67 & 68.67 \\
\hline & 9 & 88.49 & 95.15 & 79.19 & 81.41 & 87.54 & 72.85 \\
\hline & 12 & 145.68 & 152.34 & 138.49 & 134.03 & 140.15 & 127.41 \\
\hline & 15 & 164.79 & 172.34 & 159.69 & 151.61 & 158.55 & 146.91 \\
\hline \multirow{3}{*}{$\begin{array}{l}\text { LSD }(0.05) \text { cultivar } \times \text { duration } \\
\text { Significance }^{2}\end{array}$} & & 9.94 & 9.94 & 9.63 & 9.91 & 10.00 & 9.60 \\
\hline & & & & & & & \\
\hline & Wonji-Shoa & Methara & Finchaa & & & & \\
\hline Season (S) & $* *$ & $* *$ & $* *$ & & & & \\
\hline Cultivar (C) & $* *$ & $* *$ & $* *$ & & & & \\
\hline Duration (D) & $* *$ & $* *$ & $* *$ & & & & \\
\hline Cultivar $\times$ Duration & ** & $* *$ & ** & & & & \\
\hline
\end{tabular}

${ }^{1}$ The sprawling cultivars used were 'B41227' at Methara and 'N14' at Finchaa and Wonji-Shoa; and the erect cultivar 'NCo334' was used at all the plantations; ${ }^{2} \mathrm{WAP}=$ Weeks After Planting of sugarcane

2** indicates significance at $\mathrm{P}<0.01$

Among the sugarcane plantations, the highest weed dry biomass was recorded at Finchaa while the lowest weed dry biomass was recorded at Methara during both seasons (Table 1 and 2). The possible reasons for the highest weed biomass at Finchaa might be the high amount of annual rainfall (1250 $\mathrm{mm}$ ) and humidity (61\%) which might be more favorable for weed growth as compared to Methara which had the lowest amount of annual rainfall $(554 \mathrm{~mm})$ and relative humidity $(56.5 \%)$ [13]. In line with this result, [14] reported that high amount of rainfall and temperature, among other environmental factors, have influenced the periodicity of weed emergence, which often resulted in increased weed density and biomass. Similarly, [15] recorded higher weed diversity at Finchaa than at Methara and Wonji-Shoa.

In general, higher weed dry biomass was recorded in association with the erect cultivar ' $\mathrm{NCo} 334$ ' than the sprawling cultivars 'B41227' and 'N14' (Table 1 and 2). The higher weed biomass associated with the erect cultivar might be due its slow rate of canopy development to suppress the weeds as compared to the sprawling cultivars which might have exerted higher shading effect. In conformity with this result, [16] reported negative correlation between weed biomass and the associated corn leaf area.

\subsection{Cane Yield Responses}

Yield assessment due to crop-weed competition in the sugarcane plantations of Ethiopia indicated that millable cane yield varied significantly with seasons, cultivars and durations of competition. In general, at all the plantations, seasons and cultivars the cane yield was significantly decreased with increasing durations of weedy periods (Table 3 ) and with decreasing durations of weed free periods (Table 4). However, the rates of reductions were remarkable beyond weedy periods of 3 WAP (Table 3 ) and weed free periods of 12 WAP (Table 4). On the other hand, at all the plantations, weed competition up to 3 WAP had no marked effect on cane yield indicating that weeds were smaller in the early period to exert strong competition on sugarcane. In agreement with this result, $[17,18]$ indicated the important sugarcane-weed competition period to be between the first four months after planting of cane.

Among the plantations at both seasons, the highest cane yield was recorded at Methara while the lowest yield was recorded at Finchaa (Table 3 and 4) possibly due to low weed pressure and more suitable growing conditions for sugarcane production at Methara. [19] also reported that most climatic 
elements at Methara to be conducive for sugarcane vegetative growth and sucrose accumulation compared to Wonji-Shoa and Finchaa.

The maximum cane yield loss calculated as $\left(1-\frac{\text { Cane yield of weedy check }}{\text { Cane yield of weed free }}\right) \times 100$ ranged from $69.7 \%$ for sprawling cultivar 'B41227' at Methara in the first season to $83.5 \%$ for erect cultivar 'NCo334' at Wonji-Shoa at both the plantations and seasons might be due to differences in weed composition, agro-climatic conditions, field history, agronomic practices, varieties etc. Similarly, cane yield losses of $45.45 \%, 74.5 \%$ and $56.89 \%$ were reported by [20, $21,22)$, respectively, in weedy check plots.

The amount of cane yield loss recorded in the present study was higher than the one reported by [23] at Wonji-Shoa and Methara that ranged from $41-51 \%$ in the sugarcane plantations of Ethiopia. This difference could be due to the differences in major weed types prevalent in the two studies, agro-climatic and cultivar differences. The major weed species recorded were Commelina latifolia A. Rich (Commelinaceae), Cyperus rotundus L (Cyperaceae) and Ipomoea eriocarpa $\mathrm{R}$. Br. (Convolvulaceae) at Wonji-Shoa; Acalypha crenata A. Rich (Euphorbiaceae), Corchorus trilocularis L (Tiliaceae) and Cucumis dipsaceus Eprenb. ex seasons (Table 3 and 4). Such differences in yield loss among

Spach (Cucurbitaceae) at Methara; and Rottboellia cochinchinensis (Lour.) W. D. (Poaceae), Celosia trigyna L. (Amaranthaceae) and Vigna fischeri Harms. (Fabaceae). On the other hand, [4] reported cane yield loss that ranged from $64-80 \%$ in the sugarcane plantations of Ethiopia which was in agreement with our results.

Averaged over the plantations and the seasons, higher maximum yield loss (82\%) was recorded for the erect cultivar 'NCo334' as compared to sprawling cultivars (71\%) in the unweeded plots (Table 3 and 4). The high yield loss recorded for the erect cultivar could be due to its less competitive ability with weeds as compared to the sprawling cultivars as reported by [24]. Thus, the sparse crop canopy of erect cultivar might have facilitated availability of solar radiation at the soil surface, favouring weed emergence at the early growth stage of the crop that might have caused higher cane yield loss.

\subsection{Critical Periods of Weed Control}

The Gompertz and logistic equations generally described the data well and the predicted and the observed relative cane yields as affected by duration of the weed-free and weedinfested periods are shown in Figures 1, 2 and 3 for Finchaa, Methara and Wonji-shoa, respectively.

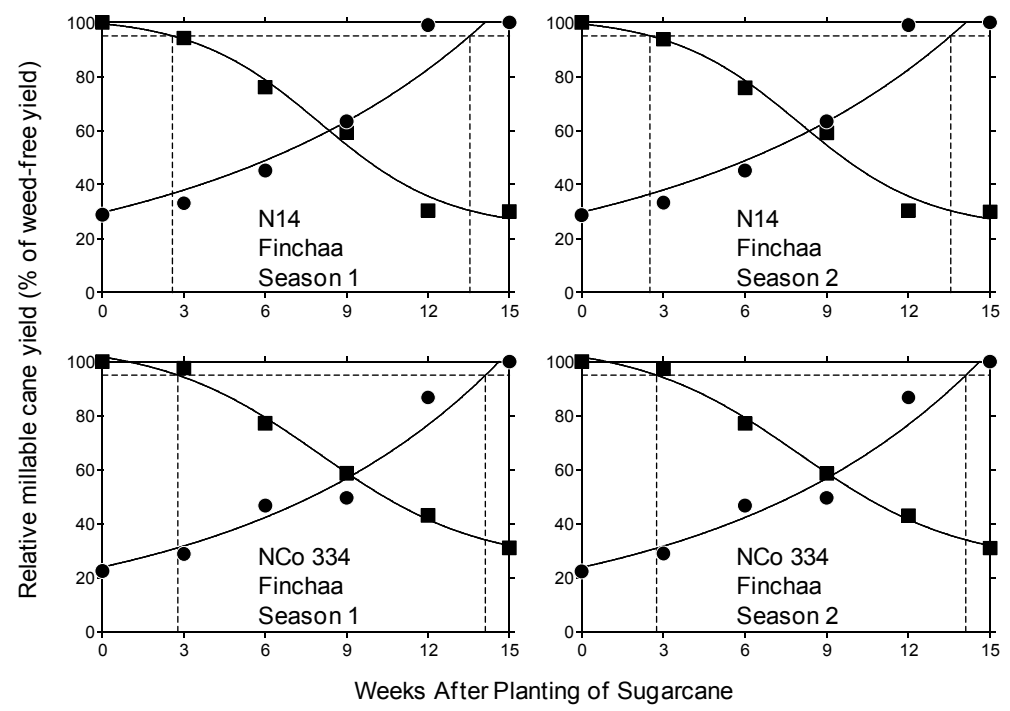

Figure 1. Effect of weed interference on relative cane yield at Finchaa. Increasing durations of weed interference (ם) and fitted curve as calculated by the logistic equation; increasing weed-free period (•) and fitted curve as calculated by the Gompertz equation. Horizontal broken line indicates the $5 \%$ acceptable cane yield loss level and the vertical broken lines indicate the starting and end of CPWC. 


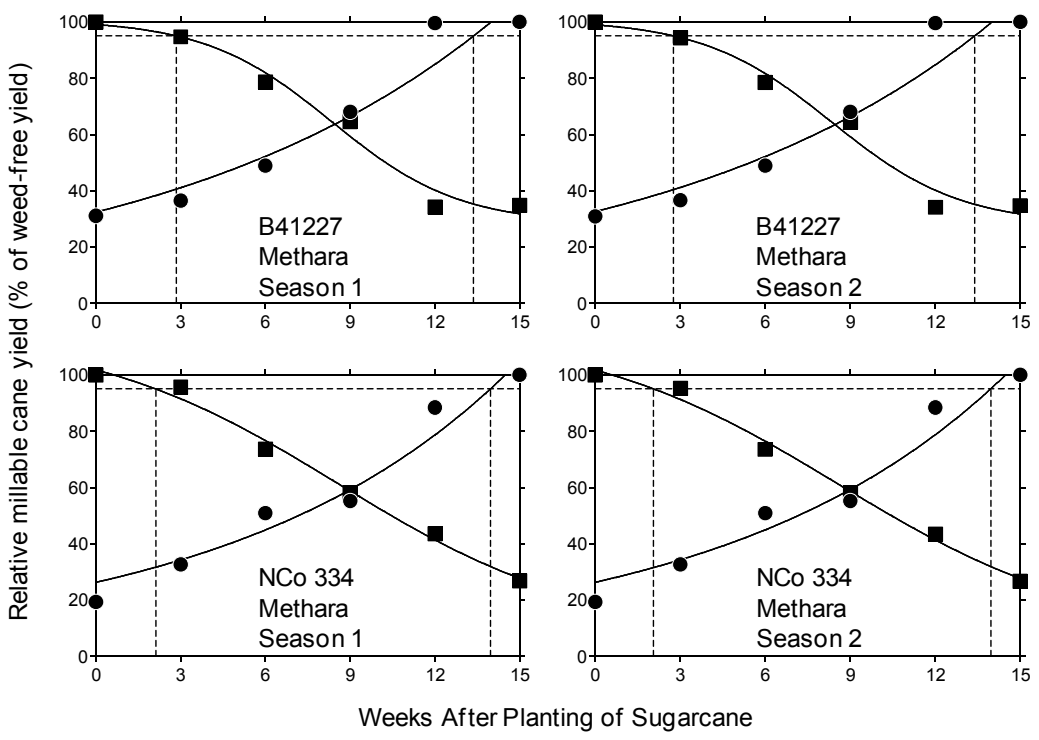

Figure 2. Effect of weed interference on relative cane yield at Methara. Increasing durations of weed interference (a) and fitted curve as calculated by the logistic equation; increasing weed-free period $(\bullet)$ and fitted curve as calculated by the Gompertz equation. Horizontal broken line indicates the $5 \%$ acceptable cane yield loss level and the vertical broken lines indicate the starting and end of CPWC.

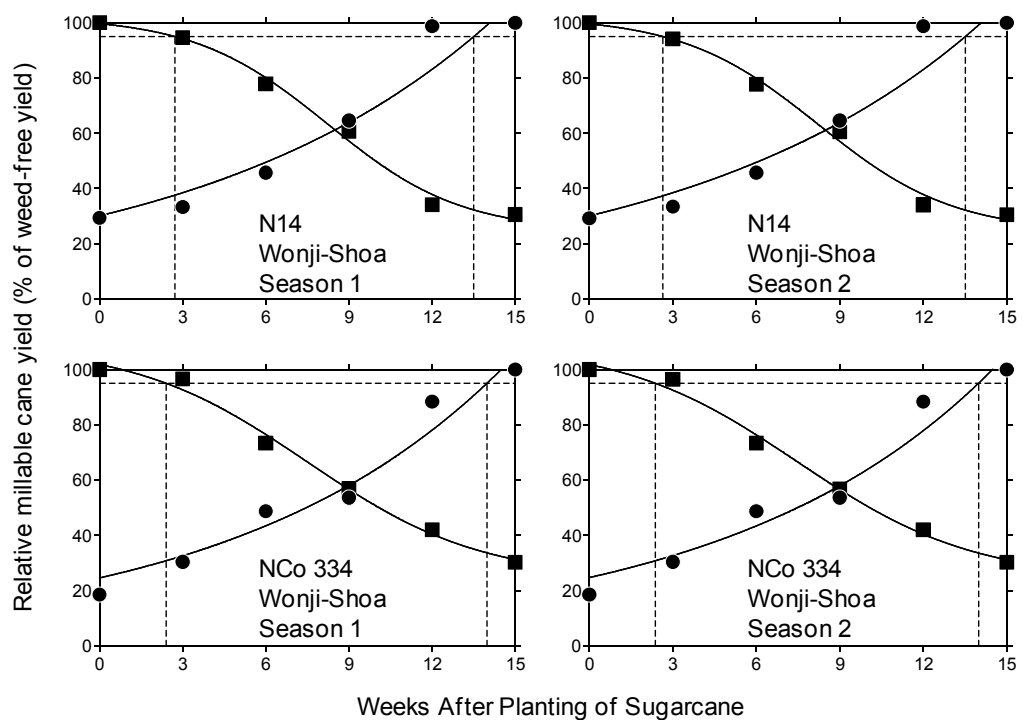

Figure 3. Effect of weed interference on relative cane yield at Wonji-Shoa. Increasing durations of weed interference (-) and fitted curve as calculated by the logistic equation; increasing weed-free period $(\bullet)$ and fitted curve as calculated by the Gompertz equation. Horizontal broken line indicates the $5 \%$ acceptable cane yield loss level and the vertical broken lines indicate the starting and end of CPWC.

The results indicated that in order to prevent more than $5 \%$ cane yield loss, the maximum time that weeds could be allowed to grow after planting of sugarcane (the beginning of the critical period) was about three weeks for the sprawling cultivars at all the plantations and about 2.5 weeks for the erect cultivar 'NCo334' at Methara and Wonji-Shoa (Figures 2 and 3) and about three weeks at Finchaa (Figure 1). These times coincided approximately with the emergence of the sprouts from the ground. In agreement with the results of this study, [22] reported that weeds should be removed immediately after the emergence to get maximum cane yield as in its early stages, sugarcane germinates and grows very slowly, while weeds show a rapid growth due to the lack of competition from the crop.

The earlier start of the critical period of weed interference at Methara and Wonji-Shoa for the erect cultivar 'NCo334' could be attributed to the earlier emergence and establishment of weeds due to the furrow irrigation used at the plantations which creates moist conditions than the sprinkler irrigation system used at Finchaa. [10] also reported that the critical period of weed interference for a given crop can vary with the relative time of weed emergence, because earlier weed emergence can lead to the earlier beginning of the critical period. Similarly, [8] reported that weed density appears to be important in the determination of the beginning of the critical period where the critical period tended to start later for experiments with lower weed density in maize (Zea mays L.). At very low weed densities there might be even no critical period of weed interference [25, 26]. Likewise, [27] indicated that relative time of weed and crop emergence and 
densities of both crop and weed may explain the variation in crop-weed interference relationship among years and locations.

In the present study, the end of the critical period of weed interference at the 5\% acceptable cane yield loss level was about 13.5 WAP for the sprawling cultivars ('N14' and 'B41227') and about 14 WAP for the erect cultivar 'NCo334' at all the plantations (Figures 1, 2 and 3). These periods coincided with the sugarcane canopy closure at the sites. The few weeds emerged after these times accumulated little above ground biomass and thus they might not have significant effect on cane yield.

The two types of cane cultivars differed slightly with regards to the onset and end of the critical period of weed competition (CPWC). On the sprawling cane cultivars, the CPWC started later (about three WAP) and ended earlier (about 13.5 WAP) compared to the erect cultivar 'NCo334' which started earlier (about 2.5 WAP) and ended late (about 14 WAP) indicating the less competitiveness of the erect cultivar. In line with this result, [28] described slower initial canopy development of sugarcane as the possible explanation for the earlier onset of the CPWC due to more competition from weeds present. Similarly, [29] reported that the late maturing cane varieties started their critical periods of weed competition at a higher growth degree days compared to the early variety.

In agreement with the results of this study, [30] reported critical period of weed control of between 30 (about four weeks) to 120 days (about 17 weeks); [31] from one month to three months after planting of sugarcane. Similarly, $[17,18$, 32] indicated that the critical sugarcane weed competition period to be between about a month (four weeks) to the first four months (16 weeks) after cane planting which was generally in the range obtained in this study.

On the other hand, the CPWC obtained in this study was narrow as compared to the result reported by [29] which was 278 Growth Degree Days (GDD) (6 WAP) for the onset of the critical periods and 835 GDD (29 WAP) for the end of the critical period for acceptable cane yield loss of 5\%. This variation could be explained by differences in environmental conditions, management practices, weed species diversity, cultivars of sugarcane etc as the CPWC has been found to vary with location, year, weed species, relative time of weed emergence, weed density, cultivars, agronomic practices etc $[10,25]$.

\section{Conclusion}

The results of this study showed higher weed dry biomass in association with the erect cultivar 'NCo334' than the sprawling cultivars 'B41227' and 'N14' possibly due its slow rate of canopy development by the erect cultivar to suppress the weeds as compared to the sprawling cultivars. As result, on the average, higher maximum yield loss (82\%) was recorded for the erect cultivar as compared to sprawling cultivars $(71 \%)$ in the unweeded plots.

The two types of sugarcane cultivars differed slightly in the onset and end of the critical period of weed competition (CPWC). For the sprawling cane cultivars, the CPWC started later (about three weeks after planting) and ended earlier (about 13.5 weeks after planting) compared to the erect cultivar 'NCo334' which started earlier (about 2.5 weeks after planting) and ended late (about 14 weeks after planting) indicating the less competitiveness of the erect cultivar.

The practical implication of this study is that herbicides or other weed control methods in sugarcane plantations of Ethiopia can be applied from 2.5 to 14 weeks after planting for the erect cultivars and from 3 to 13.5 weeks after planting for the sprawling cultivars to keep cane yield loss levels below $5 \%$.

\section{Acknowledgement}

This research was financially supported by the Ethiopian Sugar Development Agency. We thank Alemayehu Dengia, Fikru Tekele, Minjena Bekilla, Asmamaw Teshome and Getachew Cherenet for their assistance in the field work. We also thank Laila Karlsson for fitting the non-linear equations and drawing the figures.

\section{References}

[1] Shimelis K, Ambachew D, Firehun Y. 2011. Trends of sugar industry development in Ethiopia: challenges and prospects. $A$ paper presented on Ethiopian Science Academy Conference held on 28 -30 Nov. 2011. Addis Ababa, Ethiopia.

[2] ISO (International Sugar Organization). 2010. Sugar Year Book. International Sugar Organization, London. Available at URL:http://www.Isosugar.org. Accessed on 20 October 2012.

[3] McIntyre GE. 1991. Weeds of sugarcane in Mauritius: their description and control. Kin Keong Printing, Singapore.

[4] Abera T, Firehun Y and Solomon B. 2009. Review of sugarcane protection research in Ethiopia. pp. 409-447. In: Abraham T. (ed.) Increasing crop production through improved plant protection: Vol. 2. Plant Protection Society of Ethiopia, Addis Ababa, Ethiopia.

[5] Firehun Y, Abera T, Yohannes Z, Leul M. 2009. Handbook for sugarcane pest management in Ethiopia. Apple Printing Press, Addis Ababa, Ethiopia.

[6] Swanton CJ, Weise SF. 1991. Integrated weed management: rationale and approach. Weed Technology 5: 657-663.

[7] Evans SP, Knezevic SZ, Lindquist JL, Shapiro CA, Blankenship EE. 2003. Nitrogen application influences the critical period for weed control in corn. Weed Science 51:408417.

[8] Hall MR, Swanton CJ, Anderson GW. 1992. The critical period of weed control in grain corn (Zea mays). Weed Science 40:441-447.

[9] StatSoft. 1999. STATISTICA for Windows (Tulsa: StatSoft).

[10] Knezevic SZ, Evans SP, Blankenship EE, Van Acker RC, Lindquist JL. 2002. Critical period for weed control: the concept and data analysis. Weed Science 50:773-786. 
[11] Chikoye D, Ekeleme F. 2001. Weed flora and soil seed bank in fields dominated by Imperata cylindrica in the moist savannah of West Africa. Weed Research 41:475-490.

[12] Shrestha A, Knezevic SZ, Roy RC, Ball-Coelho BR, Swanton CJ. 2002. Effect of tillage, cover crop and crop rotation on the composition of weed flora in a sandy soil. Weed Research 42:76-87.

[13] Aregaw, A. 2000. Sugarcane production and sugar processing in Ethiopia. Proc. Curriculum Rev. Workshop. Jimma College of Agriculture, Jimma University.

[14] Grundy AC, Mead A. 2000. Modeling weed emergence as a function of meteorological records. Weed Science 48:594-603.

[15] Firehun Y, Tamado T. 2006. Weed flora in the Rift Valley sugarcane plantations of Ethiopia as influenced by soil types and agronomic practices. Weed Biology and Management 6:139-150.

[16] Chikoye D, Ayeoffe F, Robert A, Abebe M, Alpha K, Friday E, Nteranya S. 2008. Response of Corn Genotypes to Weed Interference and Nitrogen in Nigeria. Weed Science 56:424433.

[17] Lianming C, Chuxiong G. 2003. Sugarcane pests and their control. Guangzhou Sugarcane Industry Research Institute. Guangzhou, China. p. 62.

[18] Seeruttun S, Lutman P. 2004. Critical period of weed control in sugarcane in Mauritius. In: International Weed Science Society. Abstract book, $4^{\text {th }}$ International Weed Science Congress, Durban, Republic of South Africa, 20-24 June 2004

[19] Ambachew D, Tariku G, Bezuneh, A, Elias, T. 2009. Performance of Ethiopian Sugar Estates in 2007/08 Cropping Season: Agricultural Operations. Proceedings of Ethiopian Sugar Industry Biannual Conference 1: 186-197.

[20] Chauhan RS, Srivastava TK. 2002. Influence of planting techniques on growth and yield of sugarcane. Indian Journal of Weed Science 34: 318-319.

[21] Singh D, Tomar PK. 2003. Studies on critical period of cropweed-competition in late planted sugarcane. Indian Sugar 53: 579-583.
[22] Muhammad Z, Asif T, Zahid C, Ashraf M. 2010. Weed-crop competition effects on growth and yield of sugarcane planted using two methods. Pakistan Journal of Botany 42: 815-823.

[23] Taye E. 1991. Survey of weed flora and evaluation of some foliage-applied herbicides in the sugarcane plantation of Wonji-Shoa and Methara. MSc. thesis. Alemaya University of Agriculture, Alemaya, Ethiopia.

[24] Firehun Y, Tamado T, Abera T, Yohannes Z. 2012. Competitive ability of sugarcane (Saccharum officinarum L.) cultivars to weed interference in sugarcane plantation of Ethiopia. Crop Protection 32: 138-143.

[25] Van Acker RC, Weise SF, Swanton CJ. 1993. The critical period of weed control in soybeans [Glycine max (L.) Merr.]. Weed Science 41:194-200.

[26] Martin SG, Van Acker RC, Friesen LF. 2001. Critical period of weed control in spring canola. Weed Science 49:326-333.

[27] Lindquist JL, Mortensen DA, Westra P. 1999. Stability of corn (Zea mays)-foxtail (Setaria spp.) interference relationships. Weed Science 47:195-200.

[28] Nayamuth AR, Cheeroo-Nayamuth BF, Soopramanien GC. 1999. Agro-physiological characteristics underlying the sucrose accumulation pattern of early and late varieties. Proceedings South African Sugar Technologists Association 73:157-163.

[29] Seeruttun S. 2008. Weed management in sugar cane: critical periods of weed competition and mechanisms of interference from Paspalum paniculatum and $P$. urvillei, $\mathrm{PhD}$ thesis, University of Pretoria. On-line PDF document; URL: http://upetd.up.ac.za/thesis/. Access date: 16-December 2012.

[30] Singh G, Pant PC, Bhan VM. 1980. Studies on the critical period of weed control in spring

[31] Punzelan FL, Cruzz De La. 1981. Effect of duration of weed competition and weed control in sugarcane. Philippines Journal of Weed Sciences 8: 15-18.

[32] Srivastava TK, Singh AK, Srivastava SN. 2003. Critical period of weed competition in sugarcane ratoon. Indian Journal of Weed Science 34: 320-321. 